\title{
NILAI- NILAI RELIGI TARI DAKDENG DALAM RITUAL TOLAK BALA PADA MASYARAKAT DESA MELAYU BAGAN SERDANG KECAMATAN PANTAI LABU KABUPATEN DELI SERDANG
}

\author{
Ismail Rezeky Tanjung ${ }^{1}$, Tuti Rahayu ${ }^{2}$ \\ Program Studi Pendidikan Tari, Fakultas Bahasa dan Seni Universitas Negeri Medan. \\ Jalan Willem Iskandar Pasar V Medan Estate 20221, Sumatera Utara- Indonesia \\ Email: ${ }^{1}$ Ismailrezeky25@gmail.com, ${ }^{2}$ tutirahayu12@gmail.com
}

\begin{abstract}
This study aims to describe the Religious Values of the Dakdeng dance in the Ritual Rejection of the Malay Village Community, Bagan Serdang, Pantai Labu District, Deli Serdang Regency. The theory used in research is the theory conveyed by Kahmad. Through this theory, it will be seen from human values with God, the value of human relations with humans, and the value of human relations with nature. The time used in this study is for two months, from February to March. The location of this study was conducted in Bagan Serdang Village, Pantai Labu District, Deli Serdang Regency. The population in this study were Malay people who were in Bagan Serdang Village, Pantai Labu District, and the sample was Pawang, Keluarga, from the Tolak Bala Ritual located in Bagan Serdang Village, Pantai Labu District. Analysis of research data used is descriptive qualitative, the technique of data collection is done by observation, literature study, interviews, and documentation. The results of the research are based on the collected data. It can be seen that the Dakdeng dance represents one of the traditional art forms that uses the Ritual Reject Tool, the Rejection Ritual is a ceremony carried out on the basis of avoiding or in accordance with the djinn disease, or the guardian to disturb. The Reject Bala ritual is one of the oldest rites where it has been before and now from ancestors to the current generation. Religious values including Dakdeng dance consist of: The value of human relations with God, Value of human relations with humans, and Value human relations with nature
\end{abstract}

Keywords: Religious Values, Rituals, Reject Bala, Dakdeng Dance.

\begin{abstract}
ABSTRAK
Penelitian ini bertujuan untuk mendeskripsikan Nilai-Nilai Religi tari Dakdeng Dalam Ritual Tolak Bala Pada Masyarakat Desa Melayu Bagan Serdang Kecamatan Pantai Labu Kabupaten Deli Serdang. Teori yang digunakan dalam penelitian adalah teori yang disampaikan oleh Kahmad. Melalui teori ini akan dilihat dari nilai huibungan manusia dengan Tuhan, nilai hubungan manusia dengan manusia, dan nilai hubungan manusia dengan alam. Waktu yang di gunakan dalam penelitian ini adalah selama dua bulan, yaitu di mulai bulan Februari sampai Maret. Lokasi penelitian ini di lakukan di Desa Bagan Serdang Kecamatan Pantai Labu, Kabupaten Deli Serdang. Populasi dalam penelitian ini adalah masyarakat etnis Melayu yang berada di Desa Bagan Serdang Kecamatan Pantai Labu, dan sampel nya adalah Pawang, Keluarga keturunana Ritual Tolak Bala yang berada di Desa Bagan Serdang Kecamatan Pantai Labu. Analisis penelitian data yang digunakan adalah deskriptif kualitatif, teknik pengumpulan data di lakukan dengan obsevasi, studi pustaka, wawancara, dan dokumentasi. Hasil penelitian berdasarkan data yang terkumpul, dapat diketahui bahwa tari Dakdeng merupakan salah satu bentuk kesenian tradisional yang berfungsi sebagai sarana Ritual Tolak Bala, Ritual Tolak Bala merupakan upacara yang dilakukan atas dasar mengindari atau menolak atas suatu penyakit yang diperbuat jin, atau penunggu laut yang menggaanggu. Ritual Tolak Bala merupakan salah satu Ritual yang paling tua dimana sudah berlangsung sejak lama dan secara turun-temurun dari leluhur sampai generasi saat ini, Nilai-nilai religi yang terdapat tari Dakdeng terdiri dari: Nilai hubungan manusia dengan Tuhan, Nilai hubungan manusiadengan manusia, dan Nilai hubungan manusia dengan alam
\end{abstract}


Kata Kunci : Nilai-Nilai Religi, Ritual, Tolak Bala, Tari Dakdeng.

\section{PENDAHULUAN}

Masyarakat Melayu merupakan penduduk pribumi yang bertutur dalam bahasa Melayu, dan beradat-istiadat Melayu. Sebagian besar masyarakat Melayu mendiami wilayah bagian pesisir seperti khususnya di wilayah Pesisir Timur Sumatera Utara seperti Serdang Bedagai, Batu Bara ,dan Tanjung Balai. Masyarakat Melayu di Desa Bagan Serdang Kecamatan Pantai Labu merupakan wilayah tempat tinggalnya masyarakat Melayu Pesisir di Pantai Timur. Desa Bagan Serdang Kecamatan Pantai Labu merupakan desa yang kecil yang masyarakatnya merupakan kekeluargaan yang masih memiliki hubungan darah.

Masyarakat Melayu di Desa Bagan Serdang Kecamatan Pantai Labu merupakan masyarakat pesisir. Disebut sebagai masyarakat pesisir oleh karena masyarakat Melayu Bagan Serdang bermata pencaharian sebagai nelayan dengan memanfaatkan hamparan laut untuk tempat mencari nafkah. Nama dari Desa Bagan Serdang tersebut memiliki arti yaitu Bagan yang berarti "tepi" sedangkan Serdang sendiri diambil dari nama kabupaten daerah tersebut yaitu Deli Serdang.

Masyarakat Melayu Pesisir di Desa Bagan Serdang Kecamatan Pantai Labu ini memiliki sistem kekeluargaan yang sangat kental dengan hal-hal seperti: tolong menolong, bergotong royong, bermusyawarah dan mufakat dalam mengambil sebuah keputusan, sopan santun mereka kepada tamu, ramah dan terbuka.
Sebagaimana diketahui bahwa kebudayaan adalah hal yang kompleks yang mencakup pengetahuan, kepercayaan, kesenian, moral, hukum, adat-istiadat, dan lain kemampuankemampuan serta kebiasaan-kebiasaan yang didapat oleh manusia sebagai anggota masyarakat.

Masyarkat di Desa Bagan Serdang Kecamatan Pantai Labu melaksanakan muatan budaya itu antara lain diwujudkan dalam pelaksanaan berbagai macam bentuk kesenian tradisi yang memang menjadi arena dan sarana sosialisasi dalam kebudayaan yang telah dimantapkan lewat pewaris tradisi. Salah satu tradisi pada masyarakat di Desa Bagan Serdang Kecamatan Pantai Labu yang mengandung unsur sakral dan magis yaitu ritual tolak bala.

Menurut narasumber Bapak Umar Dani (Wawancara, 24 Juli 2017) yang mana Bapak Umar Dani adalah keturunan Datuk Panglima Kenek. Ritual tolak bala merupakan ritual salah satu jenis Ritual yang paling tua dimana sudah berlangsung sejak lama dan secara turun - menurun dari leluhur sampai generasi saat ini. Ritual tolak bala ini bermula atas suatu perjanjian antara Datuk Panglima Pawang Kenek dengan Puako. Puako merupakan kepercayaan masyarakat Melayu pesisir terhadap makhluk halus yang biasa di sebut Mambang yang dapat menguasai diri atau kehidupan seseorang. Puako tersebut dipelihara oleh Datuk Panglima Kenek untuk menjaga diri 
dan membantu dalam menjalankan kehidupan masa lalu.

Perjanjian yang dilakukan antara

Datuk Panglima Pawang Kenek terhadap puakonya, yang mana puako tersebut harus dibolo dengan cara ritual memberi makan atau persembahan seperti sesaji. Bilamana persembahan sesaji terlalaikan atau tidak dilakukan sesuai pada waktunya maka akan membawa dampak buruk bagi anak cucu. Bisa saja ada keluarga yang terkena penyakit, dan terjadinya kecelakaan saat berlaut.

Ritual tolak bala pada masyarakat di Desa Bagan Serdang Kecamatan Pantai Labu adalah satu ritual yang masih dilaksanakan untuk memohon keselamatan atas suatu penyakit atau bala. Ritual ini telah ada sejak dahulu hingga sekarang dan dilakukan secara turun menurun sampai saat ini berdasarkan perjanjian. Ritual ini dilaksanakan lima tahun sekali. Ritual tolak bala ini terdapat beberapa proses yang dilakukan seperti: bersedekah kepada anak yatim piatu, bersedekah dengan fakir miskin, setelah perlaksanaan bersedekah keesokan harinya sebelum pelaksanaan dimulai harus serah terima sesaji dan penghanyutan sesaji ke laut yang dipimpin oleh seorang Pawang. Pawang adalah merupakan seseorang yang dapat berhubungan atau berinteraksi langsung kepada makhluk gaib maupun yang sejenisnya, pawang sangat berperan penting dalam ritual tolak bala ini yang mana sebagai memulai acara sampai mengakhiri ritual tolak bala tersebut. Didalam ritual tolak bala tersebut terdapat satu tarian yang disebut dengan tarian Dakdeng.

Tari Dakdeng adalah tari yang mengandung unsur magis dan mistis dikarenakan berhubungan dengan roh-roh. Tari ini hanya dapat ditarikan oleh keturunan Datuk Pawang Kenek yang dipercayai raganya atas roh-roh Mambang dan yang memiliki puoko. Tari Dakdeng adalah tari yang didasari gerakan improvisasi sehingga tari ini tidak memiliki gerakan yang baku atau khusus seperti tari-tari pada umumnya, hal ini dikarenakan adanya rohroh Mambang yang merasuki tubuh keturunan tersebut, sehingga gerakan yang dilakukan sesuai kehendak para roh-roh Mambang dengan mengikuti suara pukulan musik pengiring, yang mana pukulan musik iringan sebagai membantu Pawang mengiringi pemanggilan roh-roh ataupun menyambut para Mambang sambil memutari sesaji. Walaupun tari Dakdeng ini didasari gerak-gerak tidak sadar secara improvisasi yang dilakukan oleh roh-roh Mambang tersebut, para Mambang melakukan gerakan seperti gerak-gerak Melayu pada umumnya seperti gerak langkah tak jadi dan silat. Tari Dakdeng ini merupakan satu kesatuan dari bagian ritual tolak bala tersebut, dimana ritual tolak bala sangat membutuhkan tari Dakdeng ini sebagai media bagi roh-roh Mambang untuk masuk kedalam tubuh penari, agar dapat berkomunikasi dengan masyarakat pelaku ritual untuk melakukan perjanjian kapan dilakukan ritual tolak bala ini kembali.

Adapun ritual yang ada di Kecamatan Pantai Labu serprti ritual Jamu Laut, Tepung 
Tawar Kampung, Kenduri Nelayan, dan Tolak Bala. Dapat dijelaskan dari hasil wawancara Kepala Desa Kecamatan Pantai Labu 12 Maret 2018, bahwa ritual Jaти Laut merupakan ritual menjamu laut yang dilakukan seluruh para nelayan atas harapan para penguasa laut atau jin laut tidak berang kepada mereka dan mereka dapat memperoleh tangkapan hasil laut yang berlimpah atas Ridho Allah. Ritual Tepung Tawar Kampung merupakan ritual yang dilakukan pada sekelompok masyarakat desa yang berada di Kecamatan Pantai Labu atas dasar meminta keselamatan kepada yang Maha kuasa untuk menjahui kampung atau desa dijauhkan dari segala marabahaya. Ritual Kenduri Nelayan merupakan ritual yang dilakukan oleh para nelayan atas dasar mengucapkan rasa syukur dan terima kasih kepada laut tempat menggantungkan hidup. Ritual Tolak Bala merupakan upacara yang dilakukan atas dasar mengindari atau menolak atas suatu penyakit, atau musibah dan dapat sebagai pengobatan penyakit yang diperbuat oleh jin, atau penunggu laut yang mengganggu. Ritual Tolak Bala merupakan salah satu jenis ritual yang paling tua dimana sudah berlangsung sejak lama dan secara turuntemurun dari leluhur sampai generasi saat ini.

Pada dasarnya manusia dalam kehidupannya mempunyai banyak kebutuhan, adanya kebutuhan inilah yang akan mendorong manusia untuk melakukan tindakan. Tindakan inilah yang diyakini masyarakat mampu memenuhi keinginan dan kebutuhan mereka, seperti halnya yang dilakukan Masyarakat di
Desa Bagan Serdang Kecamatan Pantai Labu dalam mengadakan tari dalam ritual tolak bala. Tari Dakdeng dalam ritual tolak bala ini muncul dengan iringan musik yang sangat sederhana namun khas, musik yang digunakan adalah syair yang berisi doa-doa dan mantra yang dibacakan oleh seseorang pawang, tari Dakdeng dalam ritual tolak bala ini didominasi oleh keturunan-keturunan anak cucu sebagai pelakunya dan juga memiliki mitos dan nilainilai religi tersendiri pada masyarakat sekitar.

Berdasarkan paparan tentang tari Dakdeng dalam ritual tolak bala di atas keunikan tari Dakdeng dalam ritual tolak bala inilah yang melatar belakangi penulis tentang ritual tolak bala dan nilai-nilai religi yang terkadung di dalamnya. Kata nilai religi terdiri dari dua kata, yaitu nilai dan religi. Dalam kehidupan manusia tidak pernah luput dari nilai, baik menilai maupun dinilai oleh individu lainnya. Secara umum, nilai terletak pada bagus, indah, buruk dan lain sebagainya terhadap suatu benda, fakta ataupun tindakan yang melekat pada dirinya sendiri atau orang lain. Beberapa ahli telah memberikan penjelasan secara definitive mengenai nilai. Menurut Sutrisno dan Putranto (M. Jazuli, 2014:163) nilai merupakan sesuatu yang dipandang berharga serta dijadikan acuan didalam melakukan tindakan oleh seseorang atau kelompok. Di dalam pelaksanaannya kebudayaan dapat dijadikan sarana dalam menumbuhkan dan menghayati sebuah nilai, sedangkan menurut Darji Darmodiharjo secara sederhana mengartikan nilai adalah kualitas 
atau keadaan sesuatu yang memiliki fungsi (Herimanto dan Winarn, 2013:127).

Berdasarkan uraian di atas, penulis dapat menyimpulkan bahwa nilai religi dapat dipahami sebagai pedoman atau patokan terhadap sifat, kualitas dari suatu benda maupun aktifitas keagamaan manusia yang berfungsi sebagai media komunikasi (ritual atau ibadah), ekspresi kepercayaan, dan kecintaan kepada Tuhannya. Nilai religius secara sederhana dapat dikatakan sebagai sebuah perintah atau amal, sehingga harus ada bentuk realisasi dari nilai religius atau agama tersebut yang dapat dilakukan melalui hubungan manusia dengan Tuhan, hubungan manusia dengan manusia, dan hubungan manusia dengan alam.

\section{Nilai Religi}

Suyono (2000:100) berpandangan bahwa nilai-nilai religi merupakan persamaan dari nilai-nilai agama. Selanjutnya Kahmad Dadang (2005:97) dalam Sosiologi Agama nilai religi adalah nilai yang terkait dengan hubungan antara manusia dan tuhan, nilai yang terkait dengan hubungan manusia dengan manusia, dan nilai yang terkait dengan hubungan manusia dengan alam. Berdasarkan uraian di atas, dapat disimpulkan bahwa nilai religius dapat dipahami sebagai pedoman atau patokan terhadap sifat, kualitas dari suatu benda maupun aktifitas keagamaan manusia yang berfungsi sebagai media komunikasi (ritual atau ibadah), ekspresi kepercayaan, dan kecintaan kepada Tuhannya. Nilai religius secara sederhana dapat dikatakan sebagai sebuah perintah atau amal, sehingga harus ada bentuk realisasi dari nilai religi atau agama tersebut yang dapat dilakukan melalui hubungan manusia dengan Tuhan, hubungan manusia dengan manusia, dan hubungan manusia dengan alam.

Penelitian tentang nilai-nilai religius dalam tari Dakdeng ini menggunakan pendekatan kualitatif. Pendekatan Kualitatif merupakan metode penelitian yang menghasilkan data deskriptif berupa kata-kata baik tertulis atau lisan dari orang-orang yang memberikan informasi (informan) terkait objek penelitian Basrowi \& Suwandi, (2008:23). Pendekatan kualitatif sering disebut juga sebagai pendekatan naturalistik, karena penelitiannya dilakukan pada kondisi alamiah. Dalam pendekatan kualitatif peneliti merupakan instrumen kunci penelitian dimana peneliti harus berbekal wawasan dan teori yang luas Sugiyono (2010:1).

Lokasi dalam penelitian ini adalah Desa Bagan Serdang Kecamatan Pantai Labu, Kabupaten Deli Serdang. Lokasi ini dipilih dengan memperhitungkan tempat hidup dan berkembangnya tari Dakdeng dalam ritual tolak bala. Waktu Penelitian untuk mendapatkan informasi dan data-data yang diperlukan yang berkaitan dengan materi yang akan diteliti oleh penulis yaitu dari bulan Juli 2018 sampai September 2018.

Menurut Sugiyono (2005:72) Populasi merupakan wilayah generalisasi yang terdiri atas subyek atau objek yang memiliki karakter \& kualitas tertentu yang ditetapkan oleh seorang peneliti untuk dipelajari yang kemudian ditarik sebuah kesimpulan. Berdasarkan 
pengertian diatas maka yang menjadi populasi dalam penelitian ini adalah masyarakat etnis Melayu yang berada di desa Bagan Serdang Kecamatan Pantai Labu.

Sample menurut adalah sebagian atau wakil yang diteliti. Untuk mempermudah penulisan data serta pengolahannya. Maka akan ditarik sejumlah sample dan populasi yang dianggap dapat mewakili untuk mendapatkan data-data yang akurat dalam penulisan. Begitu juga dalam mengambil data untuk menentukan populasi, maka yang penulis kerjakan adalah apabila subjeknya kurang dari 100, lebih baik diambil semua sehingga penelitiannya merupakan penelitian populasi. Dengan demikian sample penelitian ini adalah keseluruhan dari populasi. Sehingga penelitian ini disebut dengan penelitian populasi. Berdasarkan pengertian diatas maka yang menjadi sample dalam penelitian ini adalah:

a. Pawang

b. Keluarga keturunan pelasana ritual tolak bala yang berada di Desa Bagan Serdang Kecamatan Pantai Labu.

c. Pemusik

Teknik pengumpulan data merupakan langkah yang paling strategis dalam penelitian, karena tujuan utama dari penelitian adalah memperoleh data untuk di analisa agar diperoleh hasil penelitian. Adapun teknik pengumpulan data yang akan penulis lakukan pada penelitian ini untuk mendapatkan datadata mengenai nilai-nilai religi tari dakdeng adalah observasi, wawancara, dokumentasi dan studi kepustakaan.
Penulisan ini menggunakan teknik analisis kualitatif, sesuai dengan bentuk data yang terkumpul melalui wawancara, observasi, dokumentasi, dan studi kepustakaan. Hasil pengolahan data dan anilisis tersebut mungkin dapat diangkat menjadi suatu teori baru. Semua data yang diperoleh di lapangan dicatat, kemudian dianalisis dan diolah dengan secermat mungkin. Selanjutnya hasil-hasil dari pengolahan dan analisis data tersebut disusun secara sistematis dengan teknik deskriptif kualitatif, sehingga hasilnya dapat dilihat dalam satu bentuk laporan artikel ilmiah.

\section{HASIL DAN PEMBAHASAN.}

Kata Dakdeng berasal dari sebuah pukulan suara alat musik pengiring yang mengiringi tarian Dakdeng yang berbunyi “deng deng dak deng”. Dimana suara pukulan musik pengiring sangat berperan penting dalam tarian Dakdeng ini. Tari Dakdeng adalah tari yang mengandung unsur magis dan mistis dikarenakan berhubungan denga roh-roh. Tari ini hanya dapat ditarikan oleh keturunan dari Datuk Panglima Pawang Kenek yang dipercayai raganya atas roh-roh Mambang dan yang memiliki puoko. Tari Dakdeng adalah tari yang didasari gerakan improvisasi sehingga tari ini tidak memiliki gerak baku atau khusus seperti tari-tari pada umumnya, hal ini dikarenakan adanya roh-roh Mambang yang merasuki tubuh keturunan tersebut. Sehingga gerakan yang dilakukan sesuai kehendak para roh-roh Mambangdengan mengikuti suara pukulan musik pengiring, yang mana pukulan 
musik iringan sebagai pembantu Pawang mengiring pemanggilan roh-roh ataupun menyambut para Mambang keturunan tersebut dengan gerak memutari sesaji. Walaupun tari Dakdeng ini didasari gerak-gerak tidak sadar secara improvisasi yang dilakukan oleh roh-roh Mambang tersebut, para Mambang melakukan gerakan seperti dari gerak-gerak Melayu pada umumnya seperti gerak langkah tak jadi dan silat.

Tari Dakdeng dilakukan pada saat proses keterlaksanaannya ritual Tolak Bala dikarenakan tari ini adalah bagian dalam upacara Tolak Bala, yang merupakan kesatuan dan pengiring dalam ritual Tolak Bala tersebut. Dimana ritual Tolak Bala sangat membutuhkan tari Dakdeng ini sebagai media bagi roh-roh Mambang untuk masuk kedalam tubuh penari, agar dapat berkomunikasi dengan Pawang yang merupakan perantara ke keturunan atau masyarakat pelaku ritual untuk melakukan perjanjian akan dilakukan ritual Tolak Bala ini kembali pada tahunnya yaitu 5 tahun sekali.

Tari Dakdeng tersusun dari rangkaian motif gerak yang mencakup gerakan kepala, gerak tangan, dan gerak kaki menjadi satu kesatuan yang utuh yang tidak terstruktur. Gerak pada tari Dakdeng mengalun halus sebagai penggambaran sang roh-roh Mambang yang memiliki kharisma dan kewibawaan serta kesopanan pada kehidupan sehari-hari. Keberadaan tari Dakdeng dalam masyarakat tidak hanya sekedar sebagai tontonan, namun lebih mengarah kepada fungsinya, yaitu sebagai sarana ritual yang berisi pengharapan dan doa agar terhindar dari malapetaka. Dalam hal ini masyarakat Melayu Bagan Serdang mempercayai terdapat nilai-nilai religius yang berkaitan dengan komunikasi dan mendekatkan diri dengan Tuhan. Berikut bentuk realisasi dari nilai religius yang terdapat dalam tari Dakdeng:

\section{Hubungan manusia dengan Tuhan.}

Nilai hubungan manusia dengan Tuhan dapat dikatakan sebagai badah. Seperti halnya yang telah dijelaskan Kahmad Dadang dalam tulisannya tentang sosiologi agama bahwa ibadah adalah sarana untuk mendekatkan diri kepada Tuhannya, seperti halnya sholat. Selain itu, ibadah juga dapat dikatakan sebagai rasa ungkapan pengharapan untuk selalu diberikan keselamatan dan rasa syukur atas anugerah yang telah diberikan. Bentuk hubungan manusia dengan Tuhan dalam tari Dakdeng dapat dilihat dari :

\subsection{Proses tata cara pelaksanaan ritual.}

Sebelum proses pelakasanaan ritual tari Dakdeng masyarakat di Desa Bagan Serdang Kecamatan Pantai Labu melakukan kegiatan besedekah dengan anak yatim piatu, bersedekah dengan fakir miskin.

\subsection{Musik penghantar.}

Musik penghantar yang mana tari Dakdeng dalam ritual tolak bala ini muncul dengan iringan musik yang sangat sederhana tapi khas, musik yang digunakan adalaha syair yang berisi doa-doa yang dibacakan oleh seseorang Pawang.

\subsection{Ragam Gerak Tari Dakdeng}

Ragam gerak tari Dakdeng merupakan gerak membuang beras kuning pada akhir 
pementasan. Seperti yang telah diungkapkan bapak Umar Dani (Wawancara, 28 Maret 2018) Bahwa gerak tari Dakdeng merupakan prosesi berdoa yang dilakukan penari agar acara yang akan dilaksanakan berjalan lancar serta terhindar dari bala atau malapetaka. Berdasarkan penjelasan tersebut menunjukkan bahwa gerak tari Dakdeng merupakan bentuk ungkapan pengharapan manusia kepada Tuhan yang dilakukan melalui berdoa. Berdoa merupakan bentuk ibadah yang dibutuhkan oleh rohani manusia dalam menjalankan kehidupannya, dengan melakukan berdoa diharapkan manusia diberi kemudahan dalam melakukan semua kegiatan agar terhindar dari bala atau malapetaka. Selain itu, Gerak tari Dakdeng juga mengajarkan untuk membiasakan berdoa dalam kegiatan apapun, dengan harapan sebagai sarana mendekatkan diri kepada Tuhan. Doa merupakan usaha untuk memohon kepada sang pencipta atas apa yang kita harapkan dalam segala hal. Dapat dilihat dalam proses penyajian ini banyak nilai-nilai hubungan antara manusia dengan Tuhan, misalnya selalu berdoa kepada sang pencipta.

\section{Nilai Hubungan Manusia dengan}

\section{Manusia}

Manusia dianjurkan untuk selalu menjaga hubungan baik antar sesama, karena pada dasarnya manusia tidak dapat menjalani hidup sendiri atau secara individual. Hubungan manusia dengan manusia dapat dikatakan sebagai bentuk interaksi sosial, yang dalam menjalankan kehidupan bermasyarakat diperlukan sikap saling mneghormati, menghargai, serta kepedulian antara satu dengan yang lain. Bentuk interaksi sosial yang terdapat dalam pelaksanaan Ritual tari Dakdeng dapat dilihat dari:

a. Silaturahmi

Silaturahmi ini dapat dilihat saat proses penyajian awal hingga puncak acara tradisi tari Dakdeng tersebut, tidak hanya warga Bagan Serdang ikut serta antusias dalam tradisi tersebut, tetapi hampir seluruh masyarakat pantai labu.

b. Gotong Royong

Dalam ritual tolak bala terdapat gotong royong atau kebersamaan yang terjalin, antar masyarakat pendukungnya, hal ini dapat dilihat sebelum ataupun sesudah pementasan. Sebelum tradisi ini dimulai biasanya mengadakan bersihbersih bersama, serta dalam hal menyiapkan mulai dari hal kecil sampai menyediakan tempat acara diselenggarakan.

\section{Nilai Hubungan Manusia dengan}

\section{Alam}

Manusia sebagai khalifah atau pemimpin di muka bumi mempunyai tugas untuk menjaga dan mengeolah alam semesta, karena alam merupakan ciptaan Tuhan yang dapat dimanfaatkan sebagai penunjang kehidupan manusia. Nilai hubungan manusia dengan alam pada tari Dakdeng terlihat dari properti yang dipergunakan, yaitu beras kuning. Menurut Bapak Umar Dani : "Beras kuning itu inti dari tari Dakdeng yang mempunyai makna beras berarti kesuburan atau kemakmuran. Sedangkan kuning kejayaan. 
Berdasarkan penjelasan di atas, beras kuning merupakan properti utama dan inti dari tari Dakdeng. Dalam tari ini masyarakat mempercayai beras kuning yang ditaburkan sebagai tanda membuang atau mengusir malapetaka yang berhubungan jin atau setan (dalam ajaran Hindu). Beras kuning yang digunakan dalam tari Dakdeng mengadopsi dari salah satu tata cara pribadatan agama Hindu yang disebut mabija atau wabija. Bija merupakan biji beras yang dicuci lalu diwarnai dengan kunyit sehingga disebut bija kuning. Bija biasa digunakan pada akhir upacara persembayangan. Beras kuning atau bija kuning mempunyai arti keseburan dan kemakmuran. Dalam hal ini yang menjadi pembeda hanyalah penggunaanya dalam tata cara peribadatan Hindu bija atau beras kuning digunakan pada salah satu anggota badan, sedangkan pada tari Dakdeng dibuang dengan arti membuang dan mengusir hal-hal buruk.

\section{KESIMPULAN}

Berdasarkan penelitian yang telah penulis lakukan maka penulis dapat menyimpulkan dari hasil penelitian terhadap nilai religi pada tari dakdeng dalam ritual Tolak bala pada masyarakat Melayu adalah sebagai berikut :

1. Tari Dakdeng merupakan salah satu bentuk kesenian tradisional yang berfungsi sebagai Sarana Ritual tolak bala pemanggilan kekuatan Gaib.

2. Tari Dakdeng adalah bagian ritual tolak bala yang merupakan kesatuan dan pengiring dalam ritual tolak bala pada masyarakat
Melayu di Desa Bagan Serdang Kecamatan Pantai Labu.

3. Tari Dakdeng adalah tari yang mengandung unsur magis dan mistis dikarenakan berhubungan dengan roh-roh. Tari ini hanya dapat ditarikan oleh keturunan Datuk Pawang Kenek yang dipercayai raganya atas roh-roh Mambang dan yang memiliki puoko. Tari Dakdeng adalah tari yang didasari gerakan improvisasi sehingga tari ini tidak memiliki gerakan yang baku atau khusus seperti tari-tari pada umumnya, hal ini dikarenakan adanya roh-roh Mambang yang merasuki tubuh keturunan tersebut, sehingga gerakan yang dilakukan sesuai kehendak para roh-roh Mambang dengan mengikuti suara pukulan musik pengiring, yang mana pukulan musik iringan sebagai membantu Pawang mengiringi pemanggilan roh-roh ataupun menyambut para Mambang sambil memutari sesaji.

4. Tari Dakdeng mempunyai nilai-nilai religi yang berguna bagi masayarakat setempat. Nilai religi tersebut antara lain:

a. Nilai hubungan Manusia dengan Tuhan.

b. Nilai hubungan Manusia dengan Manusia.

c. Nilai hubungan Manusia dengan Alam.

\section{SARAN}

Tari Dakdeng merupakan tari yang berasal dari Pantai Labu Bagan Serdang. Tari Dakdeng ini merupakan tarian Tolak Bala dan memiliki nilai religi yang bermanfaat bagi 
masyarakat. Maka peneliti mengajukan beberapa saran sebagai berikut:

1. Agar masyarakat, khususnya generasi muda di Kabupaten Bagan Serdang mengenali dan ikut melestariakan kesenian tradisional khususnya tari Dakdeng dengan tetap menjaga dan mampu melestarikan nilai-nilai yang terkandung didalamnya.

2. Penelitian ini dapat dikembangkan lebih lanjut sehingga dapat memberikan sumbangan yang bermakna baik secara teoritis maupun praktis mengenai tari Dakdeng.

3. Kepada generasi muda masyarakat Pantai Labu khususnya dapat menjaga kelestarian kesenian tari Dakdeng dengan segala nilainilai yang ada di dalamnya.

\section{DAFTAR PUSTAKA}

Agus Bustanuddin, 2006. Agama dalam Kehidupan Manusia Pengantar Antropologi Agama. Jakarta: Rajawali Press.

Basrowi dan Suwandi, 2008. Memahami Penelitian Kualitatif. Jakarta: Rineka Cipta.

Fitri Irawati, 2015. "Fungsi Tari Dakdeng Dalam Ritual Tolak Bala Pada Masyarakat Melayu”. E-Journal of Unimed. Gesture : Jurnal Seni Tari.

Herimanto Winarno, 2013. Ilmu Sosial \& Budaya Dasar. Jakarta: Bumi Aksara.

Jamal Sangapta, 2015. “Landek Seluk Dalam Ritual Nampeken Jinujung Pada Masyarakat Karo Dalam Perspektif Struktur ". E-Journal of Unimed. Gesture : Jurnal Seni Tari.
Kahmad Dadang, 2000. Sosiologi Agama. Bandung : PT Remaja Rosdakarya.

Koentjaraningrat, 2009. Pengantar Ilmu Antropologi . Jakarta : Rineka Cipta.

Kusnadi, 2009. Penunjang Pembelajaran Seni Tari. Solo : Tiga Serangkai

Kuswarsantyo, 2011. Memahami Nilai-Nilai Filosofis Joged Mataram Sebagai Media Pembentuk Karater Anak. Yogyakarta : Universitas gajah Mada.

M Jazuli, 2014. Sosiologi Seni. Yoyakarta : Graha Ilmu.

Putra Nusa, 2013. Metode Penelitian Kualitatif Pendidikan. Jakarta : Rajawali Press.

Rohiman, 2009. Harmonisasi Agama dan Budaya di Indonesia. Jakarta : Nusantara Lestari Ceria Pratama.

Sugiyono, 2008. Statistik Untuk Penelitian . Bandung : Alfabeta.

2009. Metode Penelitian Pendidikan "Pendekatan Kuantitatif, Kualitatif, dan R\&D. Bandung : Alfabeta. Yogyakarta.

Tengku Akhirul, 2013. "Ritual Ritual Masyarakat Melayu (Kajian tentang Ritual Tolak Bala di Kecamatan Pantai Labu) ". Tesis Program Studi Antropologi Sosial. Pasca Sarjana Unimed. 